\title{
Arthropod venom Hyaluronidases: biochemical properties and potential applications in medicine and biotechnology
}

\author{
Karla C F Bordon, Gisele A. Wiezel, Fernanda G. Amorim and Eliane C. Arantes*
}

\begin{abstract}
Hyaluronidases are enzymes that mainly degrade hyaluronan, the major glycosaminoglycan of the interstitial matrix. They are involved in several pathological and physiological activities including fertilization, wound healing, embryogenesis, angiogenesis, diffusion of toxins and drugs, metastasis, pneumonia, sepsis, bacteremia, meningitis, inflammation and allergy, among others. Hyaluronidases are widely distributed in nature and the enzymes from mammalian spermatozoa, lysosomes and animal venoms belong to the subclass EC 3.2.1.35. To date, only five three-dimensional structures for arthropod venom hyaluronidases (Apis mellifera and Vespula vulgaris) were determined. Additionally, there are four molecular models for hyaluronidases from Mesobuthus martensii, Polybia paulista and Tityus serrulatus venoms. These enzymes are employed as adjuvants to increase the absorption and dispersion of other drugs and have been used in various off-label clinical conditions to reduce tissue edema. Moreover, a PEGylated form of a recombinant human hyaluronidase is currently under clinical trials for the treatment of metastatic pancreatic cancer. This review focuses on the arthropod venom hyaluronidases and provides an overview of their biochemical properties, role in the envenoming, structure/activity relationship, and potential medical and biotechnological applications.
\end{abstract}

Keywords: Hyaluronidase, Scorpion, Spider, Caterpillar, Hymenoptera, Insects, Cloning, Heterologous expression, PEGylation, Biotechnological applications

\section{Introduction}

Hyaluronidases are glycosidases that cleave preferentially the hyaluronan in the extracellular matrix (ECM) found in soft connective tissues. Hyaluronan is a linear polysaccharide formed by repeating disaccharide units of $N$ acetyl- $\beta$-D-glucosamine (GlcNAc) and $\beta$-D-glucuronic acid (GlcUA) linked via alternating $\beta-1,3$ and $\beta-1,4$ glycosidic bonds (Fig. 1). It acts as an impact absorber and lubricant in the articulations, playing a relevant structural role in maintaining the architecture of the ECM. This is rendered possible since hyaluronan interacts with many water molecules, assuming great viscoelasticity [1-3].

Hyaluronidases increase up to 20 times the infusion rates and penetration of molecules up to $200 \mathrm{~nm}$ in

\footnotetext{
* Correspondence: ecabraga@fcfrp.usp.br

Department of Physics and Chemistry, School of Pharmaceutical Sciences of Ribeirão Preto, University of São Paulo (USP), Avenida do Café, s/n, Ribeirão
} Preto, SP 14.040-903, Brazil diameter because of the cleavage of hyaluronan, reducing the obstacle that the interstitial matrix presents to fluid and drug transfer [4].

The hyaluronidase activity was identified for the first time by Duran-Reynals in 1928, but the term hyaluronidase was introduced only in $1940[5,6]$. These enzymes are widely distributed in nature and have been reported in animal venoms (such as snake [7, 8], wasp [9], scorpion [10, 11], bee [12], hornet [13], freshwater stingray [14], fish [15], spider [16], lizard [17] and caterpillar [18, 19] venoms), human organs (testis, eye, skin, spleen, liver, kidneys, uterus) and corporal fluids (placenta, tears, blood, sperm) [20, 21], bacteria [22], hookworm [23], fungi [24], bacteriophages [25], crustaceans [26], mollusks [27], leeches [28], other animal tissues [29, 30] and malignant tumors [31]. The first hyaluronidase was isolated from bovine testis [29] and has been legally sold in the USA since 1948 [32, 33]. However, the first venom hyaluronidase was isolated only in 1973 from Dugesiella 


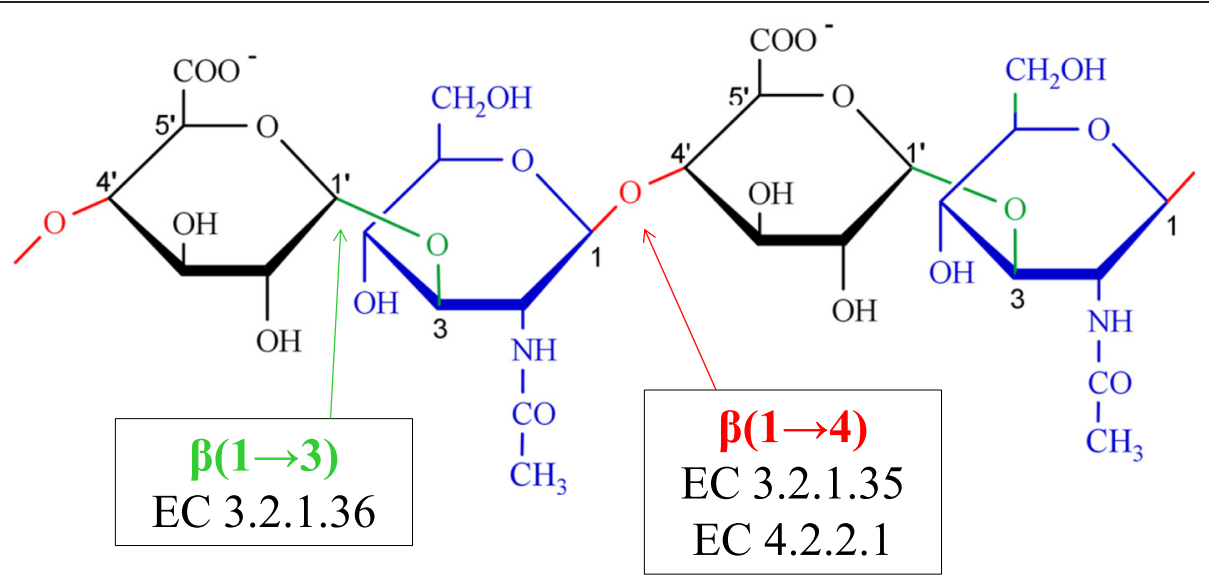

Fig. 1 Structure of hyaluronan. The repeating disaccharide units of $N$-acetyl- $\beta$-D-glucosamine (GlcNAc) and $\beta$-D-glucuronic acid (GlcUA) linked via alternating $\beta-1,3$ (highlighted in green) and $\beta-1,4$ glycosidic bonds (highlighted in red) are shown. The hyaluronidases EC 3.2.1.36 cleave the $\beta-1,3$ glycosidic bond, EC 3.2.1.35 the $\beta-1,4$ glycosidic bond and the EC 4.2.2.1 the $\beta-1,4$ glycosidic bond by elimination, yielding a double bond between carbons $4^{\prime}$ and $5^{\prime}$

hentzi tarantula venom [34]. Usually, hyaluronidases are present in venoms in such low proportion that they are not detectable through proteomic analyses [35].

Hyaluronidases are classified into three major groups $[21,36,37]$. They degrade preferentially hyaluronan, though different reaction mechanisms are involved (Fig. 2). The first group (EC 3.2.1.35) includes vertebrate enzymes (e. g. mammalian and venom hyaluronidases) that are endo- $\beta$ - $N$-acetyl-D-hexosaminidases and hydrolyze the $\beta$ 1,4 glycosidic bond between GlcNAc and GlcUA residues in hyaluronan to the tetrasaccharide (GlcUA-GlcNAcGlcUA-GlcNAc) as the main product. These enzymes are also able to cleave chondroitin sulfate. The second group (EC 3.2.1.36) is composed of hyaluronidases from annelids, such as leeches and certain crustaceans. These enzymes are endo- $\beta$ - $\mathrm{D}$-glucuronidases that degrade hyaluronan to the tetrasaccharide (GlcNAc-GlcUA-GlcNAcGlcUA) by hydrolyzing the $\beta-1,3$ glycosidic bond between GlcUA and GlcNAc residues in hyaluronan. The third one (EC 4.2.2.1, former EC 4.2.99.1) is represented by bacterial $\mathrm{N}$-acetyl-D-hexosaminidases that cleave the $\beta$ 1,4 glycosidic bond by a beta elimination reaction, degrading hyaluronan, chondroitin sulfate and dermatan sulfate to disaccharides with a double bond between carbons 4 and 5 .

The hyaluronidase activity is modulated by various activators (adrenalin, histamine and acid phosphatase found in prostate, liver, kidney, erythrocytes and platelets) and inhibitors (antihistamines, salicylates, heparin, dicoumarin, vitamin $C$ and flavonoids) [38, 39].

This enzyme has been used as an adjuvant to increase the absorption and dispersion of injected drugs [32, 40], to reduce edema $[41,42]$ and local side effects in tissues [32], and as a healing-promoting agent for skin lesions [43]. In 2005, a highly purified recombinant human hyaluronidase (rHuPH20) was approved by the FDA [32, 44]. A phase IV clinical trial using this enzyme associated to insulin analogs is under study for the treatment of type 1 diabetes [45, 46]. Additionally, a biopharmaceutical product containing rHuPH20 was approved for the treatment of adult patients with primary immunodeficiency in 2014 [40], and another one containing a PEGylated form of rHuPH20 (PEGPH20) has been under a phase II clinical trial for the first-line treatment of metastatic pancreatic cancer [47].

Many hyaluronidases (from prokaryotes and eukaryotes) have been studied and a great diversity in their activity can be observed among different species. Such diversity has been demonstrated by the optimal $\mathrm{pH}$, isoelectric point, number of isoforms, molecular mass, substrate specificity and sensitivity in the presence of various modulators [48].

Hyaluronidases are usually classified as acid-active (maximum activity from $\mathrm{pH} 3$ to $\mathrm{pH} 4$ ) or neutral-active enzymes (maximum activity from $\mathrm{pH} 5$ to $\mathrm{pH}$ 6) [49]. Hyaluronidases isolated from snake, bee and scorpion venoms are active in $\mathrm{pH}$ from 4 to 6 and present a molecular mass between 33 and $100 \mathrm{kDa}$ [50-52]. Cevallos et al. [50] observed that venom hyaluronidases from some invertebrates (Dolichovespula maculata, Vespula germanica, Pogonomyrmex rugosus and Centruroides limpidus limpidus) presented less than $50 \mathrm{kDa}$, while those from vertebrates (bovine, Heloderma horridum horridum, $H$. suspectum suspectum, Lachesis muta, Crotalus basiliscus, Bothrops asper and Micrurus nigrocinctus) are comprised of hyaluronidases larger than $60 \mathrm{kDa}$ and more than one active isoform may be present. On the other hand, small hyaluronidases (lower than $60 \mathrm{kDa}$ ) have already been identified in vertebrate venoms [7] and enzymes presenting more than $50 \mathrm{kDa}$ have already been isolated from invertebrate ones [53]. 


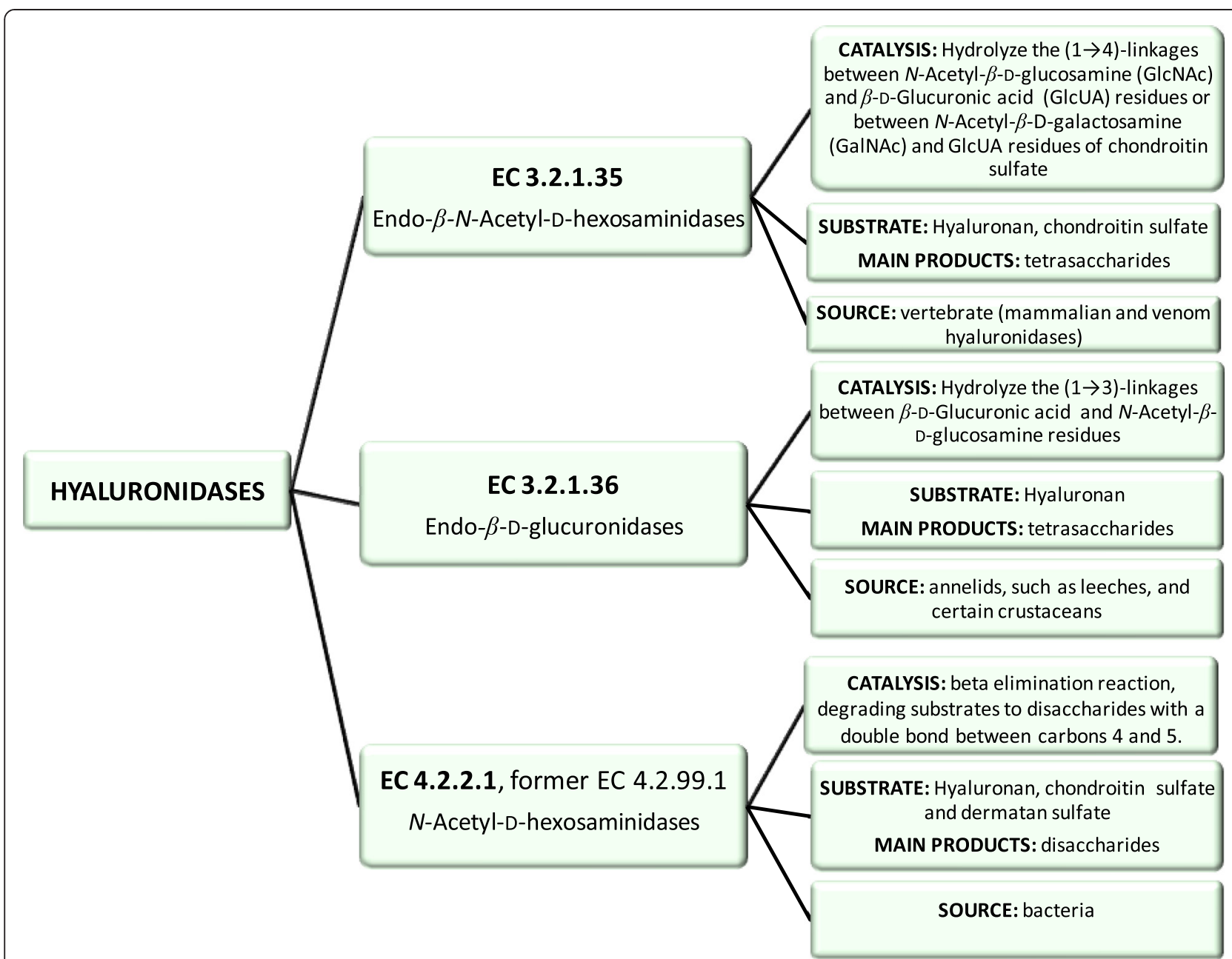

Fig. 2 The three major groups of hyaluronidases. The EC numbers, catalysis, substrates, main products and sources of each hyaluronidase group are shown

About two-thirds of all named species in the world, which corresponds to approximately 1,000,000 species, belong to the phylum Arthropoda and the class Insecta represents about $80 \%$ of this phylum. The arthropods have significant economic impact and affect all aspects of the human life. Examples include the pollination of crops and diseases spread by insects and ticks [54]. The present paper reviews the hyaluronidases present in arthropod venoms as well as their potential applications in medicine and biotechnology.

\section{Review}

Role of arthropod venom hyaluronidases in envenoming Hyaluronidases are not toxic by themselves, but they potentiate the effect of other toxins present in venoms, contributing to the local and systemic effects of envenoming $[16,55]$. Furthermore, they are described as allergens from arthropod venoms, being able to induce severe and fatal anaphylactic IgE-mediated reactions in humans $[13,56]$. These enzymes are known as "spreading factors", a concept firstly introduced by DuranReynals in 1933 [11, 57]. This action was experimentally confirmed [17], resulting in the hydrolysis of hyaluronan and chondroitin sulfates $\mathrm{A}$ and $\mathrm{C}$, which promotes the diffusion of toxins through the tissues and blood circulation of the victim/prey [7, 8, 17, 58, 59].

The hyaluronidase plays a key role in the Pararama associated phalangeal periarthritis observed after the envenoming caused by the caterpillar Premolis semirufa [60]. The enzyme from the spider Hippasa partita indirectly potentiated the myotoxicity of VRV-PL-VIII myotoxin and the effect of hemorrhagic complex-I [16]. Similar results were observed with the recombinant hyaluronidase from the spider Loxosceles intermedia, which increased the effect of the recombinant dermonecrotic toxin LiRecDT1 [55]. The enzyme from telmophage insects is responsible for extending the feeding lesion and diffusing anti-hemostatic agents into the host tissue [61]. 
Additionally, the hyaluronidase from Tityus serrulatus scorpion venom potentiates the activity of Ts1, the major neurotoxin present in this venom, increasing the serum levels of creatine kinase (CK), lactate dehydrogenase (LD) and aspartate aminotransferase (AST) [10]. Therefore, to assess the importance of hyaluronidase in the scorpion envenoming process, the toxic effects of $T$. serrultatus venom were evaluated after the in vitro and in vivo inhibition and immunoneutralization of the hyaluronidase activity by anti-hyaluronidase serum produced in rabbits [62]. In vivo neutralization assays using antihyaluronidase serum inhibited or delayed death of mice. The use of aristolochic acid, a pharmacological inhibitor of hyaluronidase, also inhibited death. On the other hand, the survival of mice was reversed after the addition of native hyaluronidase to pre-neutralized venom, showing that hyaluronidase plays a critical role in systemic envenoming [62]. Therefore, inhibitors of the hyaluronidase activity are potential first aid agents to treat envenoming cases [62,63].

\section{Structure of hyaluronidases}

There are 128 and 92 known primary sequences deposited in the NCBI and UniProt databanks, respectively, for hyaluronidases belonging to 53 genera divided into the classes Arachnida, Chilopoda and Insecta from the phylum Arthropoda (Table 1). All deposited sequences were evidenced at transcript level, with the exception of those from Phoneutria, Tityus and Dolichovespula, which were evidenced at protein level.

The first three-dimensional (3D) structure reported for a hyaluronidase belonging to the family 56 of glycoside hydrolases was reported for the enzyme from Apis mellifera venom in 2000 [PDB: 1FCQ; 1FCU; 1FCV] [64]. The overall topology of hyaluronidases from this family resembles a classical $(\beta / \alpha)_{n}$ triosephosphate isomerase (TIM) barrel, where $\mathrm{n}$ is equal to 8 in the hyaluronidase from A. mellifera venom and 7 in those from Vespula vulgaris [PDB: 2ATM] and P. paulista [Pp-Hyal, PMDB: PM0077230] venoms $[9,64,65]$.

Snake and human hyaluronidases present five disulfide bonds $[8,66]$. The disulfide bonds Cys332-Cys343, Cys336-Cys371 and Cys373-Cys383 are part of the epidermal growth factor-like (EGF-like) domain [62]. The enzymes from $A$. mellifera, $V$. vulgaris and $P$. paulista venoms show two disulfide bonds (Cys17-Cys307 and Cys183-Cys196) [9, 64, 65], which are located in the catalytic domain and well conserved in venom hyaluronidases [62]. On the other hand, the enzymes from T. serrulatus venom (TsHyal-1 and TsHyal-2, whose numbers of deposit were not stated) exhibit six disulfide bonds common to all known Arachnida hyaluronidases [62]. The sixth disulfide bond (Cys172-Cys215), found only in the Arachnida hyaluronidases, may reinforce the stability of their catalytic site [62].

On the basis of N-glycosylation, the recombinant hyaluronidase from $L$. intermedia presents four putative Nglycosylation sites in its structure; the enzyme from $A$. mellifera venom shows one of four possible sites [55, 64]. The one from $V$. vulgaris venom has three of five possible sites, the one from $P$. paulista venom shows three putative glycosylation sites, the BmHYI from Mesobuthus martensii venom presents five potential $\mathrm{N}$-glycosylation sites (the number of deposit for the molecular model was not stated), while TsHyal-1 and TsHyal-2 from T. serrulatus venom has seven and ten putative glycosylation sites, respectively $[9,62,65,67]$.

Besides the fact that $\mathrm{N}$-glycosylation sites are not conserved between TsHyal-1 and TsHyal-2, the isoforms from $T$. serrulatus venom show a variation in the active site groove in position 219. TsHyal-1 has a tyrosine (Y), while TsHyal-2 has a histidine $(\mathrm{H})$ at the same position, which may cause different substrate specificity [62]. A mutation in the positioning residue Y247 in human Hyal-4 (equivalent to Y219 in TsHyal-1) altered the substrate specificity [68]. Among the known primary sequences of hyaluronidase, only TsHyal-2 has a histidine (H) in the position 219 [62].

The residues Ser299, Asp107, and Glu109, located at surface-exposed regions of the Pp-Hyal ( $P$. paulista hyaluronidase) structure, on opposite sides of the cavity, interact with the polar hydroxyl nitrogen atoms of hyaluronan and with potential antibody-binding sites (five conformational and seven linear epitopes located at surface-exposed regions of the structure) [9]. These residues are of great importance for substrate transport into the active site through electrostatic interactions with the carboxylic groups of hyaluronan. Three amino acid residues (Asp107, Phe108, Glu109, according to the Pp-Hyal sequence) are extremely conserved and present in the active sites of all hyaluronidases [9]. Only the 3D-structure from A. mellifera hyaluronidase (Api $\mathrm{m} \mathrm{2}$ ) was solved with the substrate hyaluronan, enabling the identification of the active site and points of contact with the substrate [9]. In Api $m$ 2, the residues Asp111 and Glu113 are highly conserved in the substrate-binding site and are proton donors essential for the catalysis [64]. The structure of the complex enzyme-substrate suggests an acid-base catalytic mechanism, in which Glu113 is the proton donor and the $\mathrm{N}$-acetyl group of hyaluronan acts as the nucleophile [64].

The residues Asp111, Tyr184, Trp301 are essential for the positioning of the substrate's carbonyl of the acetamido group [21]. Tyr227 is responsible for the specificity for hyaluronan and Cys227 substitution is responsible for the chondroitinase function [21]. 
Table 1 Hyaluronidases from the phylum Arthropoda

\begin{tabular}{|c|c|c|c|c|c|c|}
\hline Class & Order & Members & Family & Genus & Number of entries (NCBl; UniProt) & Ref. \\
\hline \multirow[t]{9}{*}{ Arachnida } & \multirow[t]{3}{*}{ Araneae } & \multirow[t]{3}{*}{ Spiders } & Ctenidae & Phoneutria & $1 ; 1-F^{a}$ & - \\
\hline & & & Sicariidae & Loxosceles & $2 ; 1$ & {$[55]$} \\
\hline & & & Theraphosidae & Brachypelma & $1 ; 1-F$ & {$[82]$} \\
\hline & \multirow[t]{6}{*}{ Scorpiones } & \multirow[t]{6}{*}{ Scorpions } & Bothriuridae & Cercophonius & $1 ; 1-F$ & [129] \\
\hline & & & \multirow[t]{4}{*}{ Buthidae } & Hottentotta & $1 ; 1-F$ & [130] \\
\hline & & & & Isometroides & $1 ; 1-F$ & [129] \\
\hline & & & & Mesobuthus & $3 ; 1$ & {$[76]$} \\
\hline & & & & Tityus & $5 ; 5-F^{*}(2)$ & {$[62,74,131]$} \\
\hline & & & Urodacidae & Urodacus & $1 ; 1-F$ & [129] \\
\hline Chilopoda & Geophilomorpha & Centipedes & Linotaeniidae & Strigamia & $0 ; 2$ & - \\
\hline \multirow[t]{33}{*}{ Insecta } & Blattodea & Termites & Rhinotermitidae & Coptotermes & $1 ; 1$ & - \\
\hline & \multirow[t]{2}{*}{ Coleoptera } & \multirow[t]{2}{*}{ Beetles } & Curculionidae & Dendroctonus & $2 ; 2-F$ & [132] \\
\hline & & & Tenebrionidae & Tribolium & $2 ; 1$ & [133] \\
\hline & \multirow[t]{10}{*}{ Diptera } & Biting horseflies & Tabanidae & Tabanus & $1 ; 1$ & [134] \\
\hline & & Biting midges & Ceratopogonidae & Culicoides & $4 ; 4$ & [135-138] \\
\hline & & Black flies & Simuliidae & Simulium & $1 ; 1$ & [139] \\
\hline & & Midges & Chaoboridae & Corethrella & $1 ; 1$ & [140] \\
\hline & & \multirow[t]{4}{*}{ Mosquitos } & \multirow[t]{4}{*}{ Culicidae } & Aedes & $6 ; 4$ & [141] \\
\hline & & & & Anopheles & $4 ; 2$ & {$[142,143]$} \\
\hline & & & & Culex & $9 ; 5$ & - \\
\hline & & & & Psorophora & $1 ; 1-F$ & [144] \\
\hline & & \multirow[t]{2}{*}{ Moth flies } & \multirow[t]{2}{*}{ Psychodidae } & Lutzomyia & $2 ; 2$ & - \\
\hline & & & & Phlebotomus & $4 ; 4$ & [145-147] \\
\hline & \multirow[t]{3}{*}{ Hemiptera } & Aphids & Aphididae & Acyrthosiphon & $1 ; 1$ & - \\
\hline & & \multirow[t]{2}{*}{ Assassin bug } & \multirow[t]{2}{*}{ Reduviidae } & Rhodnius & $0 ; 3-F$ & - \\
\hline & & & & Triatoma & $1 ; 1-F$ & - \\
\hline & \multirow[t]{17}{*}{ Hymenoptera } & \multirow[t]{6}{*}{ Ants } & \multirow[t]{6}{*}{ Formicidae } & Acromyrmex & $1 ; 1$ & [148] \\
\hline & & & & Atta & $0 ; 1$ & [149] \\
\hline & & & & Camponotus & $1 ; 1$ & [150] \\
\hline & & & & Cerapachys & $1 ; 1$ & [151] \\
\hline & & & & Harpegnathos & $1 ; 1$ & [150] \\
\hline & & & & Solenopsis & $1 ; 1-F$ & {$[152]$} \\
\hline & & \multirow[t]{3}{*}{ Bees } & \multirow[t]{2}{*}{ Apidae } & Apis & $13 ; 3$ & {$[64,118]$} \\
\hline & & & & Bombus & $2 ; 0$ & - \\
\hline & & & Megachilidae & Megachile & $1 ; 0$ & - \\
\hline & & \multirow[t]{4}{*}{ Parasitoid wasps } & \multirow[t]{4}{*}{ Braconidae } & Chelonus & $4 ; 4-F$ & - \\
\hline & & & & Glyptapanteles & $5 ; 5$ & - \\
\hline & & & & Meteorus & $1 ; 1$ & - \\
\hline & & & & Microplitis & $3 ; 3$ & - \\
\hline & & Pteromalid parasitoid wasps & Pteromalidae & Nasonia & $1 ; 0$ & - \\
\hline & & Spider wasps & Pompilidae & Anoplius & $1 ; 1$ & - \\
\hline & & Wasps & Vespidae & Dolichovespula & $3 ; 1-{ }^{a}$ & [13] \\
\hline & & & & Eumenes & $1 ; 1$ & [153] \\
\hline
\end{tabular}


Table 1 Hyaluronidases from the phylum Arthropoda (Continued)

\begin{tabular}{|c|c|c|c|c|c|c|}
\hline & & & & Orancistrocerus & $1 ; 1$ & [154] \\
\hline & & & & Polistes & $2 ; 1-F$ & - \\
\hline & & & & Polybia & $2 ; 2-F$ & [9] \\
\hline & & & & Rhynchium & $1 ; 1$ & - \\
\hline & & & & Vespa & $2 ; 1$ & [155] \\
\hline & & & & Vespula & $12 ; 6$ & {$[65]$} \\
\hline & Isoptera & Dampwood termites & Termopsidae & Zootermopsis & $1 ; 1-F$ & [156] \\
\hline & Lepidoptera & Butterflies & Nymphalidae & Danaus & $2 ; 2$ & [157] \\
\hline & & Silkmoths & Bombycidae & Bombyx & $1 ; 1$ & [158] \\
\hline & Phthiraptera & Lice & Pediculidae & Pediculus & $8 ; 4$ & [159] \\
\hline TOTAL & & & & & $128 ; 92$ & \\
\hline
\end{tabular}

avidence at protein level (all the others at transcript level); F: fragment; —: unpublished

\section{Arachnida venom hyaluronidases}

\section{Scorpion venom hyaluronidases}

Scorpion venom hyaluronidases were first identified in 1975 in the venom of the South Indian scorpion Heterometrus scaber [69]. Although several studies have demonstrated the presence of hyaluronidases in scorpion venoms, few studies have reported their isolation from these sources [70-72]. This may happen because hyaluronidases are difficult to isolate, only small amounts of them are found in venoms (when compared to other toxins) and their enzymatic activity is abolished very easily [73]. These enzymes were isolated for the first time in 1990 from the venom of $H$. fulvipes in two chromatographic steps: molecular exclusion and cation-exchange chromatography [53]. Six hyaluronidases were isolated from $H$. fulvipes [53], T. serrulatus [10, 62], Palamneus gravimanus [11], T. stigmurus [74] and $M$. martensii [75] venoms and had their biochemical and structural characterization performed.

Currently, the application of "omics" techniques has enabled the identification of new compounds present in animal venoms. There are 12 and 10 known primary sequences deposited in the NCBI and UniProt databanks, respectively, for scorpion hyaluronidases (Table 1). Only two of them correspond to complete sequences: one from T. serrulatus venom [Swiss-Prot: W0HFN9] and the other from M. martensii venom [Swiss-Prot: P86100] [62, 76]. These protein sequences were deduced from cDNA sequences.

The molecular mass of scorpion venom hyaluronidases may range from 45 to $82 \mathrm{kDa}[10,53,62]$. Generally, they show maximum activity in $\mathrm{pH}$ between 4 and 6 and temperatures from 30 to $37^{\circ} \mathrm{C}$. Considerable loss of the hyaluronidase activity is observed at temperatures above $40{ }^{\circ} \mathrm{C}[10,11,53,75]$. The hyaluronidase activity can also be inhibited by heparin, as reported for the enzyme from the scorpions $H$. fulvipes, $P$. gravimanus and $M$. martensii $[11,53,75]$. Furthermore, dithiothreitol (DTT), some ions such as $\mathrm{Cu}^{2+}$ and $\mathrm{Fe}^{3+}$, and flavonoids are also able to inhibit the hyaluronidase activity $[10,53,75]$. Interestingly, the activity of these enzymes may vary among different species and changes may occur in a diet-dependent manner [77, 78]. However, distinct geographical areas had no influence on the enzyme activity [79].

\section{Spider venom hyaluronidases}

The first spider hyaluronidases, that are similar to the testicular enzyme, were reported in the venoms of the Brazilian species Lycosa raptoral and Phoneutria nigriventer in 1953 [80]. However, the first spider venom hyaluronidase was only isolated in 1973 from the tarantula Dugesiella hentzi (Girard) and was reported as the major constituent of this venom [34]. Other spider venom hyaluronidases were isolated from Loxosceles reclusa [81], Hippasa partita [16], Bracchypelma vagans [82] and Vitaluis dubius [83]. Additionally, the hyaluronidase activity was detected in several other spider venoms [8489]. Moreover, three spider venom hyaluronidases from L. leata [90], Bracchypelma vagans [82] and L. intermedia [55] were expressed in heterologous systems.

There are four and three known primary sequences deposited in the NCBI and UniProt databanks, respectively, for spider hyaluronidases (Table 1). The complete sequence of the enzyme from L intermedia [Swiss-Prot: R4J7Z9] was obtained from its venom gland transcriptome [55]. The enzyme from P. keyserlingi [Swiss-Prot: P86274] had the first 32 amino acid residues from its Nterminal identified by Edman degradation [91].

Spider venom hyaluronidases present a molecular mass that ranges from 33 to $47 \mathrm{kDa}$ in their monomeric form $[16,34,55,81-83]$ and maximum enzymatic activity at $37{ }^{\circ} \mathrm{C}$ in $\mathrm{pH}$ from 4 to $6[16,34,83,92]$. Spider venom hyaluronidases also show high specificity to hyaluronan, weak activity upon chondroitin sulfate A and an almost absence of activity upon chondroitin sulfates $B$ and $C[55,82,83]$. The activity of these hyaluronidases 
is inhibited by metal ions, such as $\mathrm{Fe}^{3+}$ and $\mathrm{Cu}^{2+}$, divalent cations, temperatures above $60{ }^{\circ} \mathrm{C}$ and extreme levels of $\mathrm{pH}$ (under 4 and over 8 ) [16, 81, 83]. The processes of thawing and freezing do not seem to influence the stability of the enzyme from $D$. hentzi and $H$. partita, whereas the enzyme from $V$. dubius venom had its activity decreased after a series of thawing and lyophilization cycles [16, 34, 83, 89].

\section{Chilopoda venom hyaluronidases}

Centipedes contain a venom gland connected to a pair of forcipules which are used to capture preys. Centipede bites usually cause burning pain, paresthesia, edema and lead to superficial necrosis in human victims [93]. The hyaluronidase activity has also been detected in the scolopendrid centipede venoms [94]. The venoms from Otostigmus pradoi and Scolopendra viridicornis showed hyaluronidase-active bands of 40-66 kDa and an additional band of $32 \mathrm{kDa}$ was detected in the first venom $[93,94]$. There are two complete primary sequences deposited to the Strigamia genus in the Uniprot databank (Table 1) although no paper has been published yet.

\section{Insecta venom hyaluronidases \\ Caterpillar venom hyaluronidases}

The larvae of butterflies and moths are called caterpillars. They produce venom in order to protect themselves against predators that are envenomed upon touching them. The composition of the venom is not well known and it varies among different species of caterpillars [95]. The presence of hyaluronidases has been reported in the venoms of Lonomia obliqua, Premolis semirufa and Megalopyge urens $[18,19,60]$. The hyaluronidase activity of the $P$. semirufa venom was measured in the presence of hyaluronan [60]. A hyaluronidase was suggested as the factor behind the Pararama associated phalangeal periarthritis, a serious public health problem among the Brazilian tappers (rubber plantation workers). It is a disease associated with joint immobilization, loss of the cartilage and bone structure and is known to be caused by the $P$. semirufa envenoming [60].

Additionally, lonoglyases are two hyaluronidases found in the L. obliqua venom that present 49 and $53 \mathrm{kDa}$ [19]. These enzymes are endo- $\beta$ - $N$-acetyl-D-hexosaminidases able to degrade hyaluronan and chondroitin sulfate. Lonoglyases show optimal activity from $\mathrm{pH} 6$ to 7 and no activity was detected below pH 5 and over pH 8 . Gouveia et al. [19] suggest that the ability of cleaving hyaluronan and chondroitin sulfate linked to the extracellular matrix could explain the effects of the venom, changing the cell adhesion and migration events. Some researchers have speculated that the degradation of the extracellular matrix results from the synergistic effect with other $L$. obliqua venom toxins, leading to local hemorrhage and renal failure [19].

\section{Diptera venom hyaluronidases}

Hyaluronidase is related to the hematophagic habit of telmophage insects, being found in the saliva of species of the genera Phlebotomus and Lutzomyia (Table 1). This enzyme extends the feeding lesion and diffuses anti-hemostatic agents into the host tissue, resulting in a microhemorrhage caused by the bite and facilitating the acquisition of blood by the insect [61]. The salivary hyaluronidase may facilitate the spreading of vectorborne microorganisms transmitted by blackflies (Simuliidae), biting midges (Ceratopogonidae) and horse flies (Tabanidae) [61].

\section{Hymenoptera venom hyaluronidases}

Proteins from social Hymenoptera (bees, wasps, and ants) venoms can trigger serious allergenic reactions in humans, such as pain, itching, inflammation and irritation, which in some cases may lead to death [96]. The hyaluronidase is among the best-studied components from the Apis genus [96]. The apian hyaluronidase is a basic glycoprotein (pI 9.0) of $41 \mathrm{kDa}$ rich in aspartic and glutamic acids, containing $7.24 \%$ carbohydrate [12].

Pp-Hyal ( $P$. paulista hyaluronidase) is a glycosyl hydrolase comprised of 338 amino acids and shares high sequence identity ( 80 to $90 \%$ ) with wasp venom hyaluronidases of the Northern hemisphere. The mature enzyme presents a theoretical pI of 8.77 and mass of 43,277 Da determined by mass spectrometry analysis [9]. Four isoforms of hyaluronidase were identified in the P. paulista venom by two-dimensional SDS-PAGE followed by mass spectrometry [97]. A 3D structural model of the most abundant isoform (Hyal III) was constructed. This isoform contains 288 amino acid residues, 44,340 Da and pI of 9.5 [98]. The comparison between the Hyal III and Pp-Hyal also showed differences in 27 amino acid residues, in the number of disulfide bonds and in the tertiary structure [9]. The levels of hyaluronidase activity in Hymenoptera venoms vary in response to physiological and environmental factors and the presence of isoforms may be an important strategy to mislead the immune system [9]. The absence of carbohydrate moieties in the bee recombinant hyaluronidase polypeptide chain did not change its antibody binding. On the other hand, this structural difference causes protein aggregation due to the partial destabilization of the molecule [99]. A heterogeneous pattern of N-glycosylation of the hyaluronidase Ves $\mathrm{v} 2$ from $V$. vulgaris was shown by mass spectrometry, disclosing peptides with three different patterns of glycosylation sites: one with glycosylation in the positions Asn79 and Asn127; another in the positions Asn79 and Asn99 and the third one with only one glycosylation 
site in the position Asn99. Because of this variation, the in vitro diagnosis of allergic individuals to wasp venom is quite complex [100].

\section{Heterologous arthropod venom hyaluronidases}

Hyaluronidases from different organisms have been expressed in various expression systems such as bacteria, yeast, plants, insects and mammalian cells $[28,55,65$, 82, 101-108].

The first recombinant hyaluronidase ever produced was the Dol $\mathrm{m} \mathrm{2}$, one of the major allergens from the white face hornet Dolichovespula maculata [13]. The recombinant Dol $\mathrm{m} 2$ compared to a native hyaluronidase from the bee venom showed a common $\mathrm{T}$ cell epitope, which may be one of the reasons why some patients have sensitivity after bee and hornet envenoming [13]. The bee venom enzyme is the most well-characterized hyaluronidase from venoms. It was expressed in 1998 by Soldatova et al. [109] in insect cells, making possible the determination of the first venom hyaluronidase crystal and the characterization of $\mathrm{N}$-glycans by mass spectrometry $[64,110]$.

\section{Potential medical and biotechnological applications of arthropod venom hyaluronidases}

There are some reports on the medical applications and off-label use of hyaluronidase in several medical fields $[32,40]$. Additionally, some hyaluronidases have been studied to enhance the therapeutic index and the local diffusion of anticancer drugs into tissues and tumors $[38,75,111-117]$. Among the arthropod venom hyaluronidases, BmHYA1 (a hyaluronidase isolated from Buthus martensi scorpion venom) reduced the expression of CD44 variant 6 in the breast cancer cell line MDA-MB-231 [75].

Furthermore, a hyaluronidase from bee venom was complexed with IgG antibody, which allows the hyaluronidase's epitope to be recognizable by the antibody and may contribute to the development of novel proteins with reduced immunogenicity to be used as a safer allergen-specific immunotherapy [118]. Recombinant allergens have been used for diagnostic and therapeutic purposes since they are obtained with consistent quality and unlimited amount [119]. Besides that, they can be modified to reduce their allergenicity and to promote beneficial immunologic properties with the aim of reducing IgE-mediated side effects after immunotherapy [119-121]. Distinct allergens which are absent or underrepresented in therapeutic venom preparations may play a key role for the success of immunotherapy [122]. The immunoglobulin $\mathrm{E}$ (IgE), present in the serum of allergic patients to the Polybia paulista wasp venom, can recognize the recombinant hyaluronidase from $P$. paulista (Pp-Hyal-rec) expressed in E. coli system [123]. A heterologous glycosylated hyaluronidase, rVes v 2 from Vespula species, expressed in insect cells system, was used to identify wasp venom allergic patients. The specific diagnosis of allergic patients was improved using the basophil activation test (BAT) with the allergen rVes v 2 when compared to the respective specific IgE detection in vitro [124]. Moreover, the carbohydrate epitopes present in the glycosylated insect cell-expressed Api m 2 are responsible for antigenic cross-reactivity to bee and wasp venoms $[104,125]$. On the other hand, the nonglycosylated E. coli-expressed Api $\mathrm{m} 2$ enabled the serologic discrimination of bee and wasp allergy, allowing the correct prescription of venom immunotherapy [125]. These reports demonstrate that recombinant antigens, such as hyaluronidases, have a great immunogenic potential in allergy diagnosis and immunotherapy [123]. In the future, molecules consisting of allergen-derived peptides bound to a viral carrier might be used for prophylactic and therapeutic allergy vaccination, since they are promising vaccines free of IgE- and T cell-mediated side effects [126].

The intranasal administration of hyaluronidase (bovine or isolated from $T$. serrulatus venom) stopped bleomycininduced lung injury and fibrosis, and decreased the TGF- $\beta$ production and collagen deposition, which makes hyaluronidase a promising tool for the recruitment of autologous MSC-like cells to the lungs in the treatment of pulmonary fibrosis [127]. This effect could be improved with the use of a delivery system of poly (D,L-lactide-coglycolide) (PLGA) microparticles (MPs) loaded with hyaluronidase (HYAL-MP) [128].

Finally, inhibitors of the hyaluronidase activity may be used as potential first aid agents in antivenom therapies since the enzyme has a relevant role in systemic envenoming [62].

\section{Conclusions}

Hyaluronidases are a frequent component from Arthropod venoms. They hydrolyze hyaluronan from the extracellular matrix, facilitating toxin diffusion into the tissues of the prey/victims. Although they are not toxins, they indirectly potentiate the toxicity of venoms. Arthropod venom hyaluronidases are potential adjuvants of anticancer drugs and promising tools for the recruitment of autologous MSC-like cells to the lungs in the treatment of pulmonary fibrosis and for the development of novel proteins to be used in allergy diagnosis and immunotherapy. The isolation and characterization of novel arthropod venom hyaluronidases can unravel much more about the role of these enzymes, which justifies the increasing interest on them and on the development of new hyaluronidase-containing drugs and biopharmaceutical products. Moreover, these studies can contribute to the development of more effective antivenom therapies. 


\section{Abbreviations}

3D: Three-dimensional; $\mathrm{CHO}$ : Chinese hamster ovary; ECM: Extracellular matrix; GlcNAc: N-acetyl- $\beta$-D-glucosamine; GlcUA: $\beta$-D-glucuronic acid; HYAL-MP: Microparticles loaded with hyaluronidase; MPs: Microparticles; PDB: Protein data bank; PLGA: Poly (D,L-lactide-co-glycolide); rHuPH20: Recombinant human $\mathrm{PH}-20$ hyaluronidase.

\section{Competing interests}

The authors declare that they have no competing interests.

\section{Authors' contributions}

KCFB and ECA are the designers of the review. KCFB, GAW and FGA drafted the manuscript. ECA is the corresponding author and supervised and critically discussed the review. All authors read and approved the final manuscript.

\section{Acknowledgements}

This study received financial support from the State of São Paulo Research Foundation (FAPESP, grant n. 2011/23236-4; scholarship to GAW, n. 2014/ 06170-8; scholarship to FGA, n. 2011/12317-3), the National Council for Scientific and Technological Development (CNPq, 303689/2013-7) and the Support Nucleus for Research on Animal Toxins (NAP-TOXAN-USP, grant $n$. 12-125432.1.3).

Received: 2 February 2015 Accepted: 8 October 2015 Published online: 22 October 2015

\section{References}

1. El-Safory NS, Fazary AE, Lee CK. Hyaluronidases, a group of glycosidases: current and future perspectives. Carbohydr Polym. 2010;81(2):165-81. doi:10.1016/j.carbpol.2010.02.047.

2. Laurent TC. Biochemistry of hyaluronan. Acta Otolaryngol Suppl. 1987;442:7-24.

3. Laurent TC, Fraser JR. Hyaluronan. FASEB J. 1992:6(7):2397-404

4. Bookbinder LH, Hofer A, Haller MF, Zepeda ML, Keller GA, Lim JE, et al. A recombinant human enzyme for enhanced interstitial transport of therapeutics. J Control Release. 2006;114(2):230-41. doi:10.1016/ j.jconrel.2006.05.027.

5. Duran-Reynalds F. Exaltation de l'activité de virus vaccinal par les extraits de certains organs. Compt Rend Soc Biol. 1928;9:6-7.

6. Meyer K, Hobby GL, Chaffee E, Dawson MH. Relationship between "spreading factor" and hyaluronidase. Proc Soc Exp Biol Med. 1940;44:294-6.

7. Pukrittayakamee S, Warrell DA, Desakorn V, McMichael AJ, White NJ, Bunnag D. The hyaluronidase activities of some Southeast Asian snake venoms. Toxicon. 1988:26(7):629-37. doi:10.1016/0041-0101(88)90245-0.

8. Bordon KC, Perino MG, Giglio JR, Arantes EC. Isolation, enzymatic characterization and antiedematogenic activity of the first reported rattlesnake hyaluronidase from Crotalus durissus terrificus venom. Biochimie. 2012;94(12):2740-8. doi:10.1016/j.biochi.2012.08.014.

9. Justo Jacomini DL, Campos Pereira FD, Pinto JRAS, dos Santos LD, da Silva Neto AJ, Giratto DT, et al. Hyaluronidase from the venom of the social wasp Polybia paulista (Hymenoptera, Vespidae): Cloning, structural modeling, purification, and immunological analysis. Toxicon. 2013;64:70-80. doi:10.1016/j.toxicon.2012.12.019.

10. Pessini AC, Takao TT, Cavalheiro EC, Vichnewski W, Sampaio SV, Giglio JR, et al. A hyaluronidase from Tityus serrulatus scorpion venom: isolation, characterization and inhibition by flavonoids. Toxicon. 2001;39(10):1495-504.

11. Morey SS, Kiran KM, Gadag JR. Purification and properties of hyaluronidase from Palamneus gravimanus (Indian black scorpion) venom. Toxicon. 2006:47(2):188-95. doi:10.1016/j.toxicon.2005.10.014.

12. Kemeny DM, Dalton N, Lawrence AJ, Pearce FL, Vernon CA. The purification and characterization of hyaluronidase from the venom of the honey bee, Apis mellifera. Eur J Biochem. 1984;139(2):217-23. doi:10.1111/j.14321033.1984.tb07997.x.

13. Lu G, Kochoumian L, King TP. Sequence identity and antigenic crossreactivity of white face hornet venom allergen, also a hyaluronidase, with other proteins. J Biol Chem. 1995:270(9):4457-65.

14. Magalhaes MR, da Silva NJ, Jr UCJ. A hyaluronidase from Potamotrygon motoro (freshwater stingrays) venom: Isolation and characterization. Toxicon. 2008;51(6):1060-7. doi:10.1016/j.toxicon.2008.01.008.
15. Poh $\mathrm{CH}$, Yuen $\mathrm{R}$, Chung MC, Khoo HE. Purification and partial characterization of hyaluronidase from stonefish (Synanceja horrida) venom. Comp Biochem Physiol B. 1992;101(1-2):159-63.

16. Nagaraju S, Devaraja S, Kemparaju K. Purification and properties of hyaluronidase from Hippasa partita (funnel web spider) venom gland extract. Toxicon. 2007:50(3):383-93. doi:10.1016/j.toxicon.2007.04.007.

17. Tu AT, Hendon RR. Characterization of lizard venom hyaluronidase and evidence for its action as a spreading factor. Comp Biochem Physiol B. 1983;76(2):377-83.

18. Ardao Ml, Perdomo CS, Pellaton MG. Venom of the Megalopyge urens (Berg) caterpillar. Nature. 1966;209(5028):1139-40.

19. Gouveia AICB, da Silveira RB, Nader HB, Dietrich CP, Gremski W, Veiga SS Identification and partial characterisation of hyaluronidases in Lonomia obliqua venom. Toxicon. 2005;45(4):403-10. doi:10.1016/j.toxicon.2004.11.008.

20. Gold EW. Purification and properties of hyaluronidase from human liver. Differences from and similarities to the testicular enzyme. Biochem J. 1982;205(1):69-74

21. Stern R, Jedrzejas MJ. Hyaluronidases: their genomics, structures, and mechanisms of action. Chem Rev. 2006;106(3):818-39. doi:10.1021/ cr050247k.

22. Hynes WL, Walton SL. Hyaluronidases of Gram-positive bacteria. FEMS Microbiol Lett. 2000;183(2):201-7. doi:S0378-1097(99)00669-2 [pii].

23. Hotez PJ, Narasimhan S, Haggerty J, Milstone L, Bhopale V, Schad GA, et al. Hyaluronidase from infective Ancylostoma hookworm larvae and its possible function as a virulence factor in tissue invasion and in cutaneous larva migrans. Infect Immun. 1992;60(3):1018-23.

24. Shimizu MT, Jorge AO, Unterkircher CS, Fantinato V, Paula CR. Hyaluronidase and chondroitin sulphatase production by different species of Candida. J Med Vet Mycol. 1995;33(1):27-31.

25. Hynes WL, Ferretti JJ. Sequence analysis and expression in Escherichia coli of the hyaluronidase gene of Streptococcus pyogenes bacteriophage H4489A. Infect Immun. 1989;57(2):533-9.

26. Karlstam B, Ljunglöf A. Purification and partial characterization of a novel hyaluronic acid-degrading enzyme from Antarctic krill (Euphausia superba). Polar Biol. 1991;11:501-7.

27. Violette A, Leonardi A, Piquemal D, Terrat $Y$, Biass D, Dutertre $S$, et al. Recruitment of glycosyl hydrolase proteins in a cone snail venomous arsenal: further insights into biomolecular features of Conus venoms. Mar Drgs. 2012;10(2):258-80. doi:10.3390/md10020258..

28. Jin P, Kang Z, Zhang N, Du G, Chen J. High-yield novel leech hyaluronidase to expedite the preparation of specific hyaluronan oligomers. Sci Rep. 2014:4:4471. doi:10.1038/srep04471.

29. Freeman ME, Anderson P, Oberg M, Dorfman A. Preparation of purified hyaluronidase from bovine testis. J Biol Chem. 1949;180(2):655-62.

30. Bollet AJ, Bonner WM, Nance JL. The presence of hyaluronidase in various mammalian tissues. J Biol Chem. 1963;238:3522-7.

31. Podyma KA, Yamagata S, Sakata K, Yamagata T. Difference of hyaluronidase produced by human tumor cell lines with hyaluronidase present in human serum as revealed by zymography. Biochem Biophys Res Commun. 1997;241(2):446-52.

32. Dunn AL, Heavner JE, Racz G, Day M. Hyaluronidase: a review of approved formulations, indications and off-label use in chronic pain management. Expert Opin Biol Ther. 2010;10(1):127-31. doi:10.1517/14712590903490382.

33. Department of Health \& Human Services: FDA Docket No. 2003P-0494/CP1 FDA 2004, [http://www.fda.gov/ohrms/dockets/dockets/05p0134/05p-0134cp00001-Tab-C-vol1.pdf]

34. Schanbacher FL, Lee CK, Wilson IB, Howell DE, Odell GV. Purification and characterization of tarantula, Dugesiella hentzi (girard) venom Hyaluronidase. Comp Biochem Physiol B. 1973;44(2):389-96.

35. Boldrini-Franca J, Correa-Netto C, Silva MM, Rodrigues RS, De La Torre P, Perez A, et al. Snake venomics and antivenomics of Crotalus durissus subspecies from Brazil: Assessment of geographic variation and its implication on snakebite management. J Proteomics. 2010;73(9):1758-76. doi:10.1016/j.jprot.2010.06.001

36. Meyer K, Rapport MM. Hyaluronidases. Adv Enzymol Relat Subj Biochem. 1952;13:199-236

37. Kreil G. Hyaluronidases - a group of neglected enzymes. Protein Sci. 1995:4(9):1666-9.

38. Menzel EJ, Farr C. Hyaluronidase and its substrate hyaluronan: biochemistry, biological activities and therapeutic uses. Cancer Lett. 1998;131(1):3-11. 
39. Li MW, Yudin Al, Van de Voort CA, Sabeur K, Primakoff P, Overstreet JW. Inhibition of monkey sperm hyaluronidase activity and heterologous cumulus penetration by flavonoids. Biol Reprod. 1997:56(6):1383-9.

40. Biopharmaceutical products in the U.S. and European markets: U.S Approvals, 2002-present. Biopharma. 2014. [http://www.biopharma.com/ approvals.html]. Accessed December 1st, 2014

41. Favorito LA, Balassiano CM, Costa WS, Sampaio FJB. Treatment of phimosis: Structural analysis of prepuce in patients submitted to topical treatment with betamethasone in association with hyaluronidase. Eur Urol Suppl. 2008;7(3):704.

42. Johnsson C, Hallgren R, Elvin A, Gerdin B, Tufveson G. Hyaluronidase ameliorates rejection-induced edema. Transpl Int. 1999;12(4):235-43. doi:10.1111/j.1432-2277.1999.tb01207.x.

43. Fronza M, Caetano GF, Leite MN, Bitencourt CS, Paula-Silva FW, Andrade TA, et al. Hyaluronidase modulates inflammatory response and accelerates the cutaneous wound healing. PLoS ONE. 2014;9(11):e112297. doi:10.1371/ journal.pone.0112297.

44. Yocum RC, Kennard D, Heiner LS. Assessment and implication of the allergic sensitivity to a single dose of recombinant human hyaluronidase injection: a double-blind, placebo-controlled clinical trial. J Infus Nurs. 2007;30(5):293-9. doi:10.1097/01.NAN.0000292572.70387.17.

45. Morrow L, Muchmore DB, Hompesch M, Ludington EA, Vaughn DE. Comparative pharmacokinetics and insulin action for three rapid-acting insulin analogs injected subcutaneously with and without hyaluronidase. Diabetes Care. 2013;36(2):273-5. doi:10.2337/dc12-0808.

46. ClinicalTrials.gov. Consistent 1. Metabolic and safety outcomes of Hylenex recombinant (hyaluronidase human injection) preadministered at CSII infusion site in participants with type 1 diabetes mellitus (T1DM). [http://clinicaltrials.gov/show/NCT01848990].

47. ClinicalTrials.gov. PEGPH20 plus Nab-paclitaxel plus Gemcitabine compared with Nab-paclitaxel plus Gemcitabine in subjects with stage IV untreated pancreatic cancer (HALO-109-202). [http://clinicaltrials.gov/show/ NCT01839487].

48. Mio K, Csóka AB, Nawy SS, Stern R. Detecting hyaluronidase and hyaluronidase inhibitors. Hyaluronan-substrate gel and -inverse substrate gel techniques. Methods Mol Biol. 2001;171:391-7. doi:10.1385/1-59259-209-0:391.

49. Girish KS, Shashidharamurthy R, Nagaraju S, Gowda TV, Kemparaju K. Isolation and characterization of hyaluronidase a "spreading factor" from Indian cobra (Naja naja) venom. Biochimie. 2004;86(3):193-202. doi:10.1016/ j.biochi.2004.02.004.

50. Cevallos MA, Navarro-Duque C, Varela-Julia M, Alagon AC. Molecular mass determination and assay of venom hyaluronidases by sodium dodecyl sulfate-polyacrylamide gel electrophoresis. Toxicon. 1992;30(8):925-30.

51. Fiszer-Szafarz B. Hyaluronidase polymorphism detected by polyacrylamide gel electrophoresis. Application to hyaluronidases from bacteria, slime molds, bee and snake venoms, bovine testes, rat liver lysosomes, and human serum. Anal Biochem. 1984;143(1):76-81. doi:0003-2697(84)90560-8 [pii].

52. Iwanaga S, Suzuki T. Enzymes in snake venom. In: Lee CY, editor. Snake venoms. Berlin: Springer; 1979. p. 95-9.

53. Ramanaiah M, Parthasarathy PR, Venkaiah B. Isolation and characterization of hyaluronidase from scorpion (Heterometrus fulvipes) venom. Biochem Int. 1990;20(2):301-10

54. Mason KA, Losos JB, Singer SR, Raven PH, Johnson GB. Coelomate Invertebrates. In: Mason KA, Losos JB, Singer SR, Raven PH, Johnson GB, editors. Biology. 9th ed. New York: McGraw-Hill; 2011. p. 666-92.

55. Ferrer VP, de Mari TL, Gremski LH, Silva DT, da Silveira RB, Gremski W, et al. A novel hyaluronidase from brown spider (Loxosceles intermedia) venom (Dietrich's hyaluronidase): from cloning to functional characterization. PLoS Negl Trop Dis. 2013;7(5), e2206. doi:10.1371/journal.pntd.0002206.

56. Kolarich D, Léonard R, Hemmer W, Altmann F. The N-glycans of yellow jacket venom hyaluronidases and the protein sequence of its major isoform in Vespula vulgaris. FEBS J. 2005;272(20):5182-90. doi:10.1111/j.17424658.2005.04841.x.

57. Duran-Reynals F. Studies on a certain spreading factor existing in bacteria and its significance for bacterial invasiveness. J Exp Med. 1933;58(2):161-81. doi:10.1084/jem.58.2.161.

58. Xu X, Wang XS, Xi XT, Liu J, Huang JT, Lu ZX. Purification and partial characterization of hyaluronidase from five pace snake (Agkistrodon acutus) venom. Toxicon. 1982;20(6):973-81.

59. Yingprasertchai S, Bunyasrisawat S, Ratanabanangkoon K. Hyaluronidase inhibitors (sodium cromoglycate and sodium auro-thiomalate) reduce the local tissue damage and prolong the survival time of mice injected with Naja kaouthia and Calloselasma rhodostoma venoms. Toxicon. 2003;42(6):635-46. doi:10.1016/j.toxicon.2003.09.001.

60. Villas-Boas IM, Gonçalves-de-Andrade RM, Squaiella-Baptistão CC, Sant'Anna OA, Tambourgi DV. Characterization of phenotypes of immune cells and cytokines associated with chronic exposure to Premolis semirufa caterpillar bristles extract. PLoS ONE. 2013;8(9), e71938. doi:10.1371/journal.pone.0071938.

61. Volfova V, Hostomska J, Cerny M, Votypka J, Volf P. Hyaluronidase of bloodsucking insects and its enhancing effect on Leishmania infection in mice. PLoS Negl Trop Dis. 2008;2(9), e294. doi:10.1371/journal.pntd.0000294.

62. Horta CCR, Magalhaes BF, Oliveira-Mendes BBR. do Carmo AO, Duarte CG, Felicori LF, et al. Molecular, immunological, and biological characterization of Tityus serrulatus venom hyaluronidase: New insights into its role in envenomation. PLoS Negl Trop Dis. 2014;8(2), e2693. doi:10.1371/ journal.pntd.0002693.

63. Girish KS, Kemparaju K. Inhibition of Naja naja venom hyaluronidase by plant-derived bioactive components and polysaccharides. Biochemistry (Mosc). 2005;70(8):948-52. doi:BCM70081145 [pii].

64. Markovic-Housley Z, Miglierini G, Soldatova L, Rizkallah PJ, Muller U, Schirmer T. Crystal structure of hyaluronidase, a major allergen of bee venom. Structure. 2000;8(10):1025-35.

65. Skov LK, Seppala U, Coen JJ, Crickmore N, King TP, Monsalve R, et al. Structure of recombinant Ves $\vee 2$ at 2.0 Angstrom resolution: structural analysis of an allergenic hyaluronidase from wasp venom. Acta Crystallogr D Biol Crystallogr. 2006;62(Pt6):595-604. doi:10.1107/ s0907444906010687.

66. Chao KL, Muthukumar L, Herzberg O. Structure of human hyaluronidase-1, a hyaluronan hydrolyzing enzyme involved in tumor growth and angiogenesis. Biochemistry. 2007;46(23):6911-20. doi:10.1021/bi700382g.

67. Xia X, Liu R, Li Y, Xue S, Liu Q, Jiang X, et al. Cloning and molecular characterization of scorpion Buthus martensi venom hyaluronidases: a novel full-length and diversiform noncoding isoforms. Gene. 2014;547(2):338-45. doi:10.1016/j.gene.2014.06.045.

68. Jedrzejas MJ, Stern R. Structures of vertebrate hyaluronidases and their unique enzymatic mechanism of hydrolysis. Proteins. 2005;61(2):227-38. doi:10.1002/prot.20592.

69. Nair RB, Kurup PA. Investigations on the venom of the South Indian scorpion Heterometrus scaber. Biochim Biophys Acta. 1975;381(1):165-74.

70. Wright RP, Chan TK, Honetschlager L, Howell DE, Odell GV. Enzymes and toxins of the scorpion venom Palamneus gravimanus. Toxicon. 1977;15(3):197-205.

71. Akhunov A, Chernetskaia II, Sadykov AS. Biochemical characteristics of the venoms of arthropods of Central Asia. Dokl Akad Nauk SSSR. 1985;285(4):1009-11.

72. Basu A, Gomes A, Dasgupta SC, Lahiri SC. Histamine, 5-HT \& hyaluronidase in the venom of the scorpion Lychas laevifrons (Pock). Indian J Med Res. 1990;92:371-3.

73. Stern R, Csoka AB. Mammalian hyaluronidases. Glycoforum/Science of Hyaluronan Today. 2000. [http://www.glycoforum.gr.jp/science/hyaluronan/ hapdf/HA15.pdf]

74. Batista CV, Roman-Gonzalez SA, Salas-Castillo SP, Zamudio FZ, GomezLagunas F, Possani LD. Proteomic analysis of the venom from the scorpion Tityus stigmurus: biochemical and physiological comparison with other Tityus species. Comp Biochem Physiol C Toxicol Pharmacol. 2007;146(1-2):147-57. doi:10.1016/j.cbpc.2006.12.004.

75. Feng L, Gao R, Gopalakrishnakone P. Isolation and characterization of a hyaluronidase from the venom of Chinese red scorpion Buthus martensi. Comp Biochem Physiol C Toxicol Pharmacol. 2008;148(3):250-7. doi:10.1016/ j.cbpc.2008.06.003.

76. Feng L, Gao R, Meng J, Gopalakrishnakone P. Cloning and molecular characterization of BmHYA1, a novel hyaluronidase from the venom of Chinese red scorpion Buthus martensi Karsch. Toxicon. 2010;56(3):474-9. doi:10.1016/j.toxicon.2010.04.009.

77. Venancio EJ, Portaro FC, Kuniyoshi AK, Carvalho DC, Pidde-Queiroz G, Tambourgi DV. Enzymatic properties of venoms from Brazilian scorpions of Tityus genus and the neutralisation potential of therapeutical antivenoms. Toxicon. 2013;69:180-90. doi:10.1016/j.toxicon.2013.02.012.

78. Pucca MB, Amorim FG, Cerni FA, Bordon KC, Cardoso IA, Anjolette FA, et al Influence of post-starvation extraction time and prey-specific diet in Tityus serrulatus scorpion venom composition and hyaluronidase activity. Toxicon. 2014;90:326-36. doi:10.1016/j.toxicon.2014.08.064. 
79. Rodríguez-Ravelo R, Coronas Fl, Zamudio FZ, González-Morales L, López GE, Urquiola AR, et al. The Cuban scorpion Rhopalurus junceus (Scorpiones, Buthidae): component variations in venom samples collected in different geographical areas. J Venom Anim Toxins incl Trop Dis. 2013;19(1):13. doi:10.1186/1678-9199-19-13.

80. Kaiser E. Trypsin and hyaluronidase inhibitor of human serum; the inhibition of the proteolytic and hyaluronic acid cleavage enzymes of snake and spider venoms by human serum. Biochem Z. 1953;324(5):344-50.

81. Wright RP, Elgert KD, Campbell BJ, Barrett JT. Hyaluronidase and esterase activities of the venom of the poisonous brown recluse spider. Arch Biochem Biophys. 1973;159(1):415-26.

82. Clement H, Olvera A, Rodriguez M, Zamudio F, Palomares LA, Possani LD, et al. Identification, cDNA cloning and heterologous expression of a hyaluronidase from the tarantula Brachypelma vagans venom. Toxicon. 2012;60(7):1223-7. doi:10.1016/j.toxicon.2012.08.018

83. Sutti R, Tamascia ML, Hyslop S, Rocha-e-Silva TA. Purification and characterization of a hyaluronidase from venom of the spider Vitalius dubius (Araneae, Theraphosidae). J Venom Anim Toxins incl Trop Dis. 2014;20(1):2. doi:10.1186/1678-9199-20-2.

84. Savel-Niemann A. Tarantula (Eurypelma californicum) venom, a multicomponent system. Biol Chem Hoppe Seyler. 1989;370(5):485-98.

85. Nagaraju S, Mahadeswaraswamy YH, Girish KS, Kemparaju K. Venom from spiders of the genus Hippasa: biochemical and pharmacological studies. Comp Biochem Physiol C Toxicol Pharmacol. 2006;144(1):1-9. doi:10.1016/ j.cbpc.2006.04.016.

86. Young AR, Pincus SJ. Comparison of enzymatic activity from three species of necrotising arachnids in Australia: Loxosceles rufescens, Badumna insignis and Lampona cylindrata. Toxicon. 2001;39(2-3):391-400.

87. Barbaro KC, Knysak I, Martins R, Hogan C, Winkel K. Enzymatic characterization, antigenic cross-reactivity and neutralization of dermonecrotic activity of five Loxosceles spider venoms of medical importance in the Americas. Toxicon. 2005;45(4):489-99. doi:10.1016/j.toxicon.2004.12.009.

88. García-Arredondo A, Rodríguez-Rios L, Díaz-Peña LF, Vega-Ángeles R. Pharmacological characterization of venoms from three theraphosid spiders: Poecilotheria regalis Ceratogyrus darlingi and Brachypelma epicureanum. J Venom Anim Toxins incl Trop Dis. 2015;21:15. doi:10.1186/s40409-015-0017-8.

89. Rocha-e-Silva TA, Sutti R, Hyslop S. Milking and partial characterization of venom from the Brazilian spider Vitalius dubius (Theraphosidae). Toxicon. 2009;53(1):153-61. doi:10.1016/j.toxicon.2008.10.026.

90. Fernandes-Pedrosa MF, Junqueira-de-Azevedo IL, Gonçalves-de-Andrade RM, Kobashi LS, Almeida DD, Ho PL, et al. Transcriptome analysis of Loxosceles laeta (Araneae, Sicariidae) spider venomous gland using expressed sequence tags. BMC Genomics. 2008;9:279. doi:10.1186/14712164-9-279.

91. Richardson M, Borges MH, Cordeiro MN, Pimenta AMC, de Lima ME, Rates B. Hyaluronidase from venom of Brazilian scorpion Tityus serrulatus. UniProtKB. 2008;P85841.

92. da Silveira RB, Chaim OM, Mangili OC, Gremski W, Dietrich CP, Nader HB, et al. Hyaluronidases in Loxosceles intermedia (brown spider) venom are endo-beta-N-acetyl-D-hexosaminidases hydrolases. Toxicon. 2007;49(6):758-68. doi:10.1016/j.toxicon.2006.11.024

93. Malta MB, Lira MS, Soares SL, Rocha GC, Knysak I, Martins R, et al. Toxic activities of Brazilian centipede venoms. Toxicon. 2008;52(2):255-63. doi:10.1016/j.toxicon.2008.05.012.

94. Undheim EA, King GF. On the venom system of centipedes (Chilopoda), a neglected group of venomous animals. Toxicon. 2011;57(4):512-24. doi:10.1016/j.toxicon.2011.01.004.

95. Kuspis DA, Rawlins JE, Krenzelok EP. Human exposures to stinging caterpillar: Lophocampa caryae exposures. Am J Emerg Med. 2001;19(5):396-8. doi:10.1053/ajem.2001.25772.

96. De Lima PR, Brochetto-Braga MR. Hymenoptera venom review focusing on Apis mellifera. J Venom Anim Toxins incl Trop Dis. 2003;9(2):149-62.

97. dos Santos LD, Santos KS, Pinto JR, Dias NB, de Souza BM, dos Santos MF, et al. Profiling the proteome of the venom from the social wasp Polybia paulista: A clue to understand the envenoming mechanism. J Proteome Res. 2010;9(8):3867-77. doi:10.1021/pr1000829.

98. Pinto JR, Santos LD, Arcuri HA, Dias NB, Palma MS. Proteomic characterization of the hyaluronidase (E.C. 3.2.1.35) from the venom of the social wasp Polybia paulista. Protein Pept Lett. 2012;19(6):625-35.

99. Soldatova LN, Marcovic-Housley Z, Luong TN, Mueller UR, Slater J. The role of glycosylation in the lgE binding of the major honeybee allergen, hyaluronidase. J Allergy Clin Immunol. 2002;109(1):S134-S. doi:10.1016/ s0091-6749(02)81524-x.

100. Seppala UR, Mutenda K, Monsalve R, Skov L, King TP, Ipsen H, et al. Analysis of $\mathrm{N}$-Glycosylation in Vespula vulgaris hyaluronidase Ves v 2. J Allergy Clin Immunol. 2006;117(2):S119-S. doi:10.1016/j.jaci.2005.12.477.

101. Berry AM, Lock RA, Thomas SM, Rajan DP, Hansman D, Paton JC. Cloning and nucleotide sequence of the Streptococcus pneumoniae hyaluronidase gene and purification of the enzyme from recombinant Escherichia coli. Infect Immun. 1994;62(3):1101-8.

102. Gmachl M, Kreil G. Bee venom hyaluronidase is homologous to a membrane protein of mammalian sperm. Proc Natl Acad Sci U S A. 1993;90(8):3569-73.

103. Bakke M, Kamei J, Obata A. Identification, characterization, and molecular cloning of a novel hyaluronidase, a member of glycosyl hydrolase family 16 , from Penicillium spp. FEBS Lett. 2011;585(1):115-20. doi:10.1016/j.febslet.2010.11.021.

104. King TP, Lu G, Gonzalez M, Qian N, Soldatova L. Yellow jacket venom allergens, hyaluronidase and phospholipase: Sequence similarity and antigenic cross-reactivity with their hornet and wasp homologs and possible implications for clinical allergy. J Allergy Clin Immunol. 1996;98(3):588-600. doi:10.1016/s0091-6749(96)70093-3.

105. Reitinger S, Boroviak T, Laschober GT, Fehrer C, Müllegger J, Lindner H, et al. High-yield recombinant expression of the extremophile enzyme, bee hyaluronidase in Pichia pastoris. Protein Expr Purif. 2008:57(2):226-33. doi:10.1016/j.pep.2007.10.001

106. Li H, Yang J, Chen Y, Guan L, Du L, Guo Y, et al. Expression of a functional recombinant oleosin-human hyaluronidase $\mathrm{hPH}-20$ fusion in Arabidopsis thaliana. Protein Expr Purif. 2014;103:23-7. doi:10.1016/j.pep.2014.03.007.

107. Jung $Y$, Jung MY, Park JH, Jung GC, Hong YS, Yeom CH, et al. Production of human hyaluronidase in a plant-derived protein expression system: plantbased transient production of active human hyaluronidase. Protein Expr Purif. 2010;74(2):181-8. doi:10.1016/j.pep.2010.06.003.

108. Frost Gl, Csoka AB, Wong T, Stern R. Purification, cloning, and expression of human plasma hyaluronidase. Biochem Biophys Res Commun. 1997;236(1):10-5. doi:10.1006/bbrc.1997.6773.

109. Soldatova LN, Crameri R, Gmachl M, Kemeny DM, Schmidt M, Weber M, et al. Superior biologic activity of the recombinant bee venom allergen hyaluronidase expressed in baculovirus-infected insect cells as compared with Escherichia coli. J Allergy Clin Immunol. 1998;101(5):691-8.

110. Soldatova LN, Tsai C, Dobrovolskaia E, Marković-Housley Z, Slater JE. Characterization of the $\mathrm{N}$-glycans of recombinant bee venom hyaluronidase (Api m 2) expressed in insect cells. Allergy Asthma Proc. 2007;28(2):210-5.

111. Lee JH, Moore LD, Kumar S, Pritchard DG, Ponnazhagan S, Deivanayagam C. Bacteriophage hyaluronidase effectively inhibits growth, migration and invasion by disrupting hyaluronan-mediated Erk1/2 activation and RhoA expression in human breast carcinoma cells. Cancer Lett. 2010;298(2):238-49. doi:10.1016/j.canlet.2010.07.011.

112. Civalleri D, Esposito M, De Cian F, Balletto N, Vannozzi MO, Mondini G, et al. Effects of adjuvant hyaluronidase in tumors refractory to chemotherapy. Review of the literature and pharmacokinetics of cisplatin after regional administration in animals and humans. G Chir. 1997;18(4):175-81.

113. Klocker J, Sabitzer H, Raunik W, Wieser S, Schumer J. Hyaluronidase as additive to induction chemotherapy in advanced squamous cell carcinoma of the head and neck. Cancer Lett. 1998;131(1):113-5. doi:10.1016/s03043835(98)00207-9.

114. Baumgartner G, Gomar-Hoss C, Sakr L, Ulsperger E, Wogritsch C. The impact of extracellular matrix on the chemoresistance of solid tumors - experimental and clinical results of hyaluronidase as additive to cytostatic chemotherapy. Cancer Lett. 1998;131(1):85-99. doi:10.1016/s0304-3835(98)00204-3.

115. Spruss T, Bernhardt G, Schonenberger H, Schiess W. Hyaluronidase significantly enhances the efficacy of regional vinblastine chemotherapy of malignant melanoma. J Cancer Res Clin Oncol. 1995;121(4):193-202. doi:10.1007/bf01366962.

116. Shuster S, Frost Gl, Csoka AB, Formby B, Stern R. Hyaluronidase reduces human breast cancer xenografts in SCID mice. Int J Cancer. 2002;102(2):192-7. doi:10.1002/ijc.10668.

117. Jacobson A, Rahmanian M, Rubin K, Heldin P. Expression of hyaluronan synthase 2 or hyaluronidase 1 differentially affect the growth rate of transplantable colon carcinoma cell tumors. Int J Cancer. 2002;102(3):212-9. doi:10.1002/ijc.10683.

118. Padavattan S, Schirmer T, Schmidt M, Akdis C, Valenta R, Mittermann I, et al. Identification of a B-cell epitope of hyaluronidase, a major bee venom 
allergen, from its crystal structure in complex with a specific fab. J Mol Biol. 2007;368(3):742-52. doi:10.1016/j.jmb.2007.02.036.

119. Valenta R, Niederberger V. Recombinant allergens for immunotherapy. J Allergy Clin Immunol. 2007;119(4):826-30. doi:10.1016/j.jaci.2007.01.025

120. Cromwell O, Hafner D, Nandy A. Recombinant allergens for specific immunotherapy. J Allergy Clin Immunol. 2011;127(4):865-72. doi:10.1016/ j.jaci.2011.01.047.

121. Rolland JM, Gardner LM, O'Hehir RE. Allergen-related approaches to immunotherapy. Pharmacol Ther. 2009;121(3):273-84. doi:10.1016/ j.pharmthera.2008.11.007

122. Kohler J, Blank S, Mueller S, Bantleon F, Frick M, Huss-Marp J, et al. Component resolution reveals additional major allergens in patients with honeybee venom allergy. J Allergy Clin Immunol. 2014;133(5):1383-9. doi:10.1016/j.jaci.2013.10.060.

123. Justo Jacomini DL, Gomes Moreira SM, Campos Pereira FD, Zollner RL, Brochetto Braga MR. Reactivity of IgE to the allergen hyaluronidase from Polybia paulista (Hymenoptera, Vespidae) venom. Toxicon. 2014;82:104-11. doi:10.1016/j.toxicon.2014.02.016.

124. Balzer L, Pennino D, Blank S, Seismann H, Darsow U, Schnedler M, et al. Basophil activation test using recombinant allergens: highly specific diagnostic method complementing routine tests in wasp venom allergy. PLOS ONE. 2014;9(10), E108619. doi:10.1371/journal.pone.0108619.

125. Mittermann I, Zidarn M, Silar M, Markovic-Housley Z, Aberer W, Korosec P, et al. Recombinant allergen-based lgE testing to distinguish bee and wasp allergy. J Allergy Clin Immunol. 2010;125(6):1300-7. doi:10.1016/j.jaci.2010.03.017.

126. Valenta R, Niespodziana K, Focke-Tejkl M, Marth K, Huber H, Neubauer A, et al. Recombinant allergens: What does the future hold? J Allergy Clin Immunol. 2011;127(4):860-4. doi:10.1016/j.jaci.2011.02.016.

127. Bitencourt CS, Pereira PA, Ramos SG, Sampaio SV, Arantes EC, Aronoff DM, et al. Hyaluronidase recruits mesenchymal-like cells to the lung and ameliorates fibrosis. Fibrogenesis Tissue Repair. 2011:4(1):3. doi:10.1186/ 1755-1536-4-3.

128. Bitencourt CS, Gelfuso GM, Pereira PA, Assis PA, Tefé-Silva C, Ramos SG, et al. Hyaluronidase-loaded PLGA microparticles as a new strategy for the treatment of pulmonary fibrosis. Tissue Eng Part A. 2015;1-2:246-56. doi:10.1089/ten.TEA.2013.0403.

129. Sunagar K, Undheim EAB, Chan AHC, Koludarov I, Munoz-Gomez SA, Antunes $A$, et al. Evolution stings: the origin and diversification of scorpion toxin peptide scaffolds. Toxins. 2013;5(12):2456-87. doi:10.3390/ toxins5122456.

130. Morgenstern D, Rohde BH, King GF, Tal T, Sher D, Zlotkin E. The tale of a resting gland: transcriptome of a replete venom gland from the scorpion Hottentotta judaicus. Toxicon. 2011;57(5):695-703. doi:10.1016/j.toxicon.2011.02.001.

131. de Oliveira UC, Candido DM, Dorce VA. Junqueira-de-Azevedo I de L. The transcriptome recipe for the venom cocktail of Tityus bahiensis scorpion. Toxicon. 2015;95:52-61. doi:10.1016/j.toxicon.2014.12.013.

132. Keeling Cl, Yuen MM, Liao NY, Docking TR, Chan SK, Taylor GA, et al. Draft genome of the mountain pine beetle, Dendroctonus ponderosae Hopkins, a major forest pest. Genome Biol. 2013;14(3):R27. doi:10.1186/gb-2013-14-3-r27.

133. Richards S, Gibbs RA, Weinstock GM, Brown SJ, Denell R, Beeman RW, et al. The genome of the model beetle and pest Tribolium castaneum. Nature. 2008:452(7190):949-55. doi:10.1038/nature06784.

134. Ma D, Li Y, Dong J, An S, Wang Y, Liu C, et al. Purification and characterization of two new allergens from the salivary glands of the horsefly. Tabanus yao Allergy. 2011;66(1):101-9. doi:10.1111/j.1398-9995.2010.02435.x

135. Russell CL, Heesom KJ, Arthur CJ, Helps CR, Mellor PS, Day MJ, et al. Identification and isolation of cDNA clones encoding the abundant secreted proteins in the saliva proteome of Culicoides nubeculosus. Insect Mol Biol. 2009;18(3):383-93. doi:10.1111/j.1365-2583.2009.00882.x.

136. Campbell CL, Vandyke KA, Letchworth GJ, Drolet BS, Hanekamp T, Wilson WC. Midgut and salivary gland transcriptomes of the arbovirus vector Culicoides sonorensis (Diptera: Ceratopogonidae). Insect Mol Biol. 2005;14(2):121-36. doi:10.1111/j.1365-2583.2004.00537.x.

137. Schaffartzik A, Marti E, Torsteinsdottir S, Mellor PS, Crameri R, Rhyner C. Selective cloning, characterization, and production of the Culicoides nubeculosus salivary gland allergen repertoire associated with equine insect bite hypersensitivity. Vet Immunol Immunopathol. 2011;139(2-4):200-9. doi:10.1016/j.vetimm.2010.10.015.

138. van der Meide NM, Roders N, van Oldruitenborgh-Oosterbaan MMS, Schaap PJ, van Oers MM, Leibold W, et al. Cloning and expression of candidate allergens from Culicoides obsoletus for diagnosis of insect bite hypersensitivity in horses. Vet Immunol Immunophatol. 2013;153(3-4):227-39. doi:10.1016/j.vetimm.2013.03.005.

139. Chagas AC, Calvo E, Pimenta PF, Ribeiro JM. An insight into the sialome of Simulium guianense (Diptera:Simuliidae), the main vector of River Blindness Disease in Brazil. BMC Genomics. 2011;12:612. doi:10.1186/1471-2164-12-612.

140. Ribeiro JMC, Chagas AC, Pham VM, Lounibos LP, Calvo E. An insight into the sialome of the frog biting fly, Corethrella appendiculata. Insect Biochem Molec Biol. 2013;44:23-32. doi:10.1016/j.ibmb.2013.10.006.

141. Nene V, Wortman JR, Lawson D, Haas B, Kodira C, Tu ZJ, et al. Genome sequence of Aedes aegypti, a major arbovirus vector. Science. 2007;316(5832):1718-23. doi:10.1126/science.1138878.

142. Holt RA, Subramanian GM, Halpern A, Sutton GG, Charlab R, Nusskern DR, et al. The genome sequence of the malaria mosquito Anopheles gambiae. Science. 2002;298(5591):129-49. doi:10.1126/science.1076181.

143. Marinotti O, Cerqueira GC, de Almeida LG, Ferro MI, Loreto EL, Zaha A, et al. The genome of Anopheles darlingi, the main neotropical malaria vector. Nucleic Acids Res. 2013;41(15):7387-400. doi:10.1093/nar/gkt484.

144. Chagas AC, Calvo E, Rios-Velasquez CM, Pessoa FAC, Medeiros JF, Ribeiro JMC. A deep insight into the sialotranscriptome of the mosquito, Psorophora albipes. BMC Genomics. 2013;14:875. doi:10.1186/1471-2164-14-875.

145. Hostomska J, Volfova V, Mu J, Garfield M, Rohousova I, Volf P, et al. Analysis of salivary transcripts and antigens of the sand fly Phlebotomus arabicus. BMC Genomics. 2009;10:282. doi:10.1186/1471-2164-10-282.

146. Rohousova I, Subrahmanyam S, Volfova V, Mu J, Volf P, Valenzuela JG, et al Salivary gland transcriptomes and proteomes of Phlebotomus tobbi and Phlebotomus sergenti, vectors of leishmaniasis. PLoS Negl Trop Dis. 2012;6(5), e1660. doi:10.1371/journal.pntd.0001660.

147. Vlkova M, Sima M, Rohousova I, Kostalova T, Sumova P, Volfova V, et al. Comparative analysis of salivary gland transcriptomes of Phlebotomus orientalis sand flies from endemic and non-endemic foci of visceral leishmaniasis. PLoS Negl Trop Dis. 2014;8(2), e2709. doi:10.1371/journal.pntd.0002709.

148. Nygaard S, Zhang G, Schiott M, Li C, Wurm Y, Hu H, et al. The genome of the leaf-cutting ant Acromyrmex echinatior suggests key adaptations to advanced social life and fungus farming. Genome Res. 2011;21(8):1339-48. doi:10.1101/gr.121392.111.

149. Suen G, Teiling C, Li L, Holt C, Abouheif E, Bornberg-Bauer E, et al. The genome sequence of the leaf-cutter ant Atta cephalotes reveals insights into its obligate symbiotic lifestyle. PLoS Genet. 2011;7(2), e1002007. doi:10.1371/ journal.pgen.1002007.

150. Bonasio R, Zhang G, Ye C, Mutti NS, Fang X, Qin N, et al. Genomic comparison of the ants Camponotus floridanus and Harpegnathos saltator. Science. 2010;329(5995):1068-71. doi:10.1126/science.1192428.

151. Oxley PR, Ji L, Fetter-Pruneda I, McKenzie SK, Li C, Hu H, et al. The genome of the clonal raider ant Cerapachys biroi. Curr Biol. 2014;24(4):451-8. doi:10.1016/j.cub.2014.01.018.

152. Wurm Y, Wang J, Riba-Grognuz O, Corona M, Nygaard S, Hunt BG, et al. The genome of the fire ant Solenopsis invicta. Proc Natl Acad Sci U S A. 2011;108(14):5679-84. doi:10.1073/pnas.1009690108.

153. Baek JH, Lee SH. Differential gene expression profiles in the venom gland/ sac of Eumenes pomiformis (Hymenoptera: Eumenidae). Toxicon. 2010;55(6):1147-56. doi:10.1016/j.toxicon.2010.01.004.

154. Baek JH, Woo TH, Kim CB, Park JH, Kim H, Lee S, et al. Differential gene expression profiles in the venom gland/sac of Orancistrocerus drewseni (Hymenoptera: Eumenidae). Arch Insect Biochem Physiol. 2009;71(4):205-22. doi:10.1002/arch.20316

155. An S, Chen L, Wei JF, Yang X, Ma D, Xu X, et al. Purification and characterization of two new allergens from the venom of Vespa magnifica. PLoS ONE. 2012;7(2), e31920. doi:10.1371/journal.pone.0031920.

156. Terrapon N, Li C, Robertson HM, Ji L, Meng X, Booth W, et al. Molecular traces of alternative social organization in a termite genome. Nat Commun. 2014;5:3636. doi:10.1038/ncomms4636.

157. Zhan S, Merlin C, Boore JL, Reppert SM. The monarch butterfly genome yields insights into long-distance migration. Cell. 2011;147(5):1171-85. doi:10.1016/j.cell.2011.09.052.

158. Xia Q, Wang J, Zhou Z, Li R, Fan W, Cheng D, et al. The genome of a lepidopteran model insect, the silkworm Bombyx mori. Insect Biochem Mol Biol. 2008;38(12):1036-45. doi:10.1016/j.ibmb.2008.11.004.

159. Kirkness EF, Haas BJ, Sun W, Braig HR, Perotti MA, Clark JM, et al. Genome sequences of the human body louse and its primary endosymbiont provide insights into the permanent parasitic lifestyle. Proc Natl Acad Sci U S A. 2010;107(27):12168-73. doi:10.1073/pnas.1003379107. 